\title{
An unusual presentation of a severely calcified subserous leiomyoma in a postmenopausal woman: a case report
}

\author{
Sunil Kumar Samal*, Setu Rathod, Reddi Rani, R. Anandraj
}

Department of Obstetrics \& Gynecology, Mahatma Gandhi Medical College \& Research Institute, Pillaiyarkuppam607402, Pondicherry, India

Received: 31 March 2014

Accepted: 14 April 2014

\section{*Correspondence:}

Dr. Sunil Kumar Samal,

E-mail: drsksamal1981@gmail.com

(C) 2014 Samal SK et al. This is an open-access article distributed under the terms of the Creative Commons Attribution Non-Commercial License, which permits unrestricted non-commercial use, distribution, and reproduction in any medium, provided the original work is properly cited.

\begin{abstract}
We report a case of a 58-year-old postmenopausal woman presented with mass descending per vaginum with lower abdominal discomfort for last one year. Examination revealed second stage utero-vaginal prolapse according to Pelvic organ prolapsed quantification (POP-Q) system with a hard mobile mass of size $6 \times 6 \mathrm{~cm}$ in pouch of Douglas. After workup, it was diagnosed as posterior subserosal calcified leiomyoma of FIGO (International Federation of Gynaecology and Obstetrics) class 6. Vaginal hysterectomy with pelvic floor repair was done and histopathological examination confirmed a calcified leiomyoma.
\end{abstract}

Keywords: Postmenopausal, Subserosal calcified leiomyoma, Uterovaginal prolapse

\section{INTRODUCTION}

Uterine fibroids constitute one of the most ubiquitous benign tumours encountered by gynaecologist all over the world which composed mainly of smooth muscle cells and varying amounts of fibrous tissue. An incidence of $20-50 \%$ is frequently quoted by various authors and histopathology studies of hysterectomy specimens. ${ }^{1}$ Postmenopausal shrinkage of fibroid occurs in $70-90 \%$ of the women $^{2}$ and only few cases of postmenopausal severely calcified leiomyomas have been reported in the literature. $^{3,4}$

\section{CASE REPORT}

A 58-year-old postmenopausal lady presented to our department with mass descending per vaginum and occasional lower abdominal pain since one year. She is $\mathrm{P}_{2} \mathrm{~L}_{2}$, all full term normal delivery, last child birth 25 years back and was ligated. The patient had regular menstruation from menarche (12 years) to menopause (48 years), and never took hormone replacement therapy.
General and systemic examination revealed no abnormality. On local examination there was second stage utero-vaginal prolapsed according to Pelvic organ prolapsed quantification (POP-Q) system which was reducible. Per vaginum examination revealed retroverted bulky uterus and one hard mobile mass of size $6 \times 6 \mathrm{~cm}$ in the pouch of Douglas. A provisional diagnosis of posterior subserosal calcifying leiomyoma was made with a differential diagnosis of a solid fibrotic ovarian tumour. All standard laboratory tests were within normal range including the CA-125, which was $14.2 \mathrm{U} / \mathrm{mL}$. Pelvic ultrasound revealed posterior subserosal fibroid. A kidney, ureter, and bladder x-ray (KUB) (Figure 1) showed a severely calcified mass in the pelvic cavity suggestive of a calcified leiomyoma. Final diagnosis of second stage utero-vaginal prolapse with posterior subserosal calcified leiomyoma was made and the patient was planned for vaginal hysterectomy with pelvic floor repair. Apart from this consent was also taken for laparotomy and abdominal hysterectomy if required. Vaginal hysterectomy with pelvic floor repair was done and the myoma was found to be FIGO class 6 . On gross examination, a hard mass of size $6 \times 6 \mathrm{~cm}$ with the 
exposed surface containing smooth muscle, adipose tissue and bony fragments (Figure 2). Histopathological examination after fixation and decalcification confirmed the diagnosis of leiomyoma with hyalinization and dystrophic calcification. The patient was discharged four days after the surgery and on follow-up, there were no further problems noted.

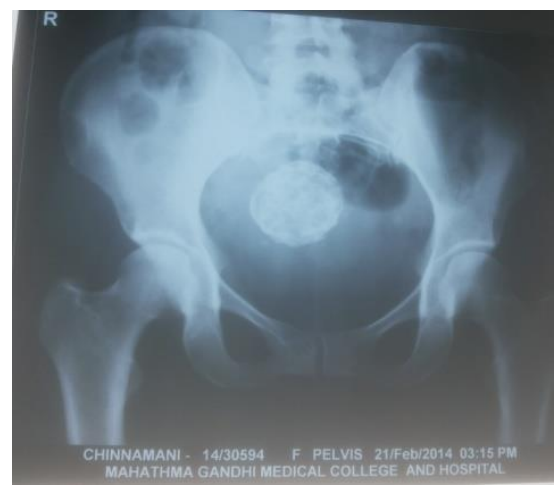

Figure 1: X-ray KUB showing severely calcified mass in pelvis.

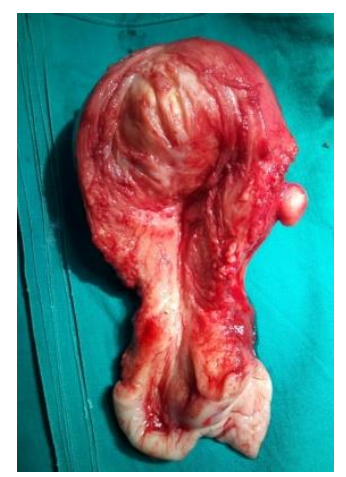

Figure 2: Gross specimen showing calcified fibroid.

\section{DISCUSSION}

Leiomyomas are rarely found in postmenopausal women because their growth is thought to be estrogen dependent and most of them regress after menopause. As leiomyomas enlarge, they may outgrow their blood supply, resulting in various types of degeneration: hyaline or myxoid degeneration, calcification, cystic degeneration, or red degeneration. ${ }^{5}$ In general, hyaline degeneration is the most common (63\%) form of degeneration, while the others occur less frequently, such as myxomatous changes (13\%), calcification (8\%), mucoid changes $(6 \%)$, cystic degeneration $(4 \%)$, red degeneration $(3 \%)$, and fatty changes $(3 \%){ }^{6}$ Calcified degeneration commonly seen in menopausal age group, black women and in women who have pedunculated subserous tumour. They become radioopaque due to the presence of calcium in them and so they are known as "Wombstones".

Although most of fibroids regress after menopause, there are a few reported cases of leiomyoma growth in postmenopausal women. ${ }^{7,8}$ Kawamura et al. ${ }^{8}$ suggested that other estrogens or growth factors, such as estrone, Insulin-Like Growth Factors (IGF), or Epidermal Growth Factors (EGF), might play a role in the growth of leiomyomas in postmenopausal women. Lumsden et al. and Vollenhoven et al. suggested that an association of polypeptide growth factors such as Platelet Derived Growth Factors (PDGF), transforming growth factors, and Vascular Endothelial Growth Factors (VEGF), stimulated the growth of leiomyomas. ${ }^{4}$ Many of these growth factors are overexpressed in leiomyomas and either increase smooth muscle proliferation (TGF transforming growth factor, FGF - fibroblast growth factors) or DNA synthesis (EGF, PDGF), stimulate synthesis of extracellular matrix (TGF- $\beta$ ), and promote mitogenesis (TGF- $\beta$, EGF, IGF, prolactin), or angiogenesis (FGF, VEGF). ${ }^{9}$ If a postmenopausal woman is obese, peripheral conversion of adrenal derived androstenedione to estrone by aromatization of fat might stimulate the growth of leiomyomas. ${ }^{4}$

Clinically significant subserous and intramural fibroids can usually be diagnosed by pelvic examination based on findings of an enlarged, irregularly shaped, firm and nontender uterus. Routine sonographic examination is not necessary when the diagnosis is almost certain. However, a definite diagnosis of submucous fibroids often requires saline-infusion sonography, hysteroscopy, or magnetic resonance imaging. ${ }^{10}$ The FIGO fibroid classification system $^{10}$ categorises submucosal, intramural, subserosal, and transmural fibroids (Table 1). According to this classification, our case was found to be of class 6 .

Table 1: FIGO leiomyoma classification system. ${ }^{10}$

\begin{tabular}{|c|c|c|}
\hline & Class & \\
\hline \multirow{3}{*}{ SM-Submucosal } & 0 & Pedunculated intracavitary \\
\hline & 1 & $<50 \%$ intramural \\
\hline & 2 & $\geq 50 \%$ intramural \\
\hline \multirow{6}{*}{ O-Other } & 3 & $\begin{array}{l}\text { Contacts endometrium; } 100 \% \\
\text { intramural }\end{array}$ \\
\hline & 4 & Intramural \\
\hline & 5 & Subserosal $\geq 50 \%$ intramural \\
\hline & 6 & Subserosal $<50 \%$ intramural \\
\hline & 7 & Subserosal pedunculated \\
\hline & 8 & $\begin{array}{l}\text { Other (Specify e.g. cervical, } \\
\text { parasitic) }\end{array}$ \\
\hline \multirow{2}{*}{$\begin{array}{l}\text { Hybrid } \\
\text { leiomyomas } \\
\text { impact both } \\
\text { endometrium and } \\
\text { serosa) }\end{array}$} & \multirow[t]{2}{*}{$2-5$} & $\begin{array}{l}\text { Two numbers are listed } \\
\text { separately by a hyphen. By } \\
\text { convention, the first refers to the } \\
\text { relationship with the } \\
\text { endometrium while the second } \\
\text { refers to the relationship to the } \\
\text { serosa. For example- }\end{array}$ \\
\hline & & $\begin{array}{l}\text { Submucosal and subserosal, } \\
\text { each with less than half the } \\
\text { diameter in the endometrial and } \\
\text { peritoneal cavities, respectively. }\end{array}$ \\
\hline
\end{tabular}


Funding: No funding sources

Conflict of interest: None declared

Ethical approval: Not required

\section{REFERENCES}

1. Cramern SF, Patel A. The frequency of uterine leiomyomas. Am J Clin Pathol. 1990;94:435-38.

2. Ross RK, Pike M, Vessey MP et al. Risk factors for uterine fibroids and reduced risk associated with oral contraceptives. Br Med J. 1986;293:359-62.

3. Singh K, Prasad D, Pankaj S, Suman S, Kumar A, Choudhary $\mathrm{V}$ et al. Postmenopausal massive subserous calcified fibroid: a case report. J Evol Med Dent Sci. 2014;3(9):2255-7.

4. Hwang JH, Modi GV, Lee JK. An unusual presentation of a severely calcified parasitic leiomyoma in a postmenopausal woman. J Soc Laparoendoscop Surg. 2010;14(2):299-302.

5. Murase E, Siegelman ES, Outwater EK, Perez-Jaffe LA, Tureck RW. Uterine leiomyomas: histopathologic features, MR imaging findings, differential diagnosis, and treatment. Radiographics. 1999;19:1179-97.
6. Persaud V, Arjoon PD. Uterine leiomyoma. Incidence of degenerative change and a correlation of associated symptoms. Obstet Gynecol. 1970;35:432-6.

7. Rajab KE, Aradi AN, Datta BN. Postmenopausal leiomyomatosis peritonealis disseminata. Int $\mathbf{J}$ Gynecol Obstet. 2000;68:271-2.

8. Kawamura N, Ito F, Ichimura $\mathrm{T}$ et al. Transient rapid growth of uterine leiomyoma in a postmenopausal woman. Oncol Rep. 1999;6:1289-92.

9. Flake GP, Andersen J, Dixon D. Etiology and pathogenesis of uterine leiomyomas: a review. Environ Health Perspect. 2003;111:1037-54.

10. Parker WH. Uterine fibroids. In: Berek JS, eds. Berek \& Novak's Gynaecology. 15th ed. New Delhi: Wolters Kluwer Health/Lippincott Williams \& Wilkins; 2012: 444-445.

DOI: $10.5455 / 2320-1770 . i j r \operatorname{cog} 20140638$

Cite this article as: Samal SK, Rathod S, Reddi R, Anandraj R. An unusual presentation of a severely calcified subserous leiomyoma in a postmenopausal woman: a case report. Int J Reprod Contracept Obstet Gynecol 2014;3:463-5. 